\title{
Role of flow cytometry in multiple myeloma and the prognostic significance of CD87 (uPAR) expression
}

\author{
Multipl miyelomda akım sitometrinin rolü ve CD87 (uPAR) \\ ekspresyonunun prognostik önemi
}

\author{
Murat Albayrak ${ }^{1}$ Özlem Şahin Balçık ${ }^{1}$, Simten Dağdaş², Mesude Yılmaz², Funda

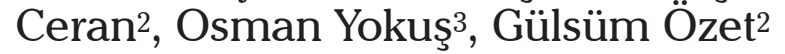 \\ 'Department of Hematology, Dr. Abdurrahman Yurtarslan Ankara Oncology Education and Research Hospital, Ankara, Turkey \\ 2Department of Hematology, Ankara Numune Education and Research Hospital, Ankara, Turkey \\ ${ }^{3}$ Department of Hematology, Istanbul Göztepe Education and Research Hospital, Istanbul, Turkey
}

\begin{abstract}
Objective: The plasminogen activator system consists of the serine protease urokinase plasminogen activator (uPA), two endogenous inhibitors of PAI-1 (plasminogen activator inhibitor-1) as well as the PAI-2 and uPA receptor (uPAR or CD87). The aim of this study was to determine the significance of flow cytometry and CD87, CD45 and CD56 expressions in the diagnosis, follow-up and prognosis of multiple myeloma (MM).

Materials and Methods: Twenty-nine MM patients were included in the study. Bone marrow samples were used for flow cytometry. A panel of CD87, CD45, CD56, CD10, CD19, CD20, CD38, and CD138 was tested by flow cytometry.

Results: CD87 was negative in 8 (27.5\%) cases, dim positive in 9 (31.1\%) and bright positive in $12(41.4 \%)$. CD87 expression was significantly higher in CD45 (-) cases.

Conclusion: Flow cytometry has a significant role in the diagnosis and prognosis of MM. Further clinical studies including large numbers of patients are needed to determine the prognostic role of CD87 in MM. (Turk J Hematol 2010; 27: 182-9)

Key words: Multiple myeloma, uPA, CD87 (uPAR), flow cytometry

Received: October 5, 2009

Accepted: March 22, 2010

\section{Özet}

Amaç: Plazminojen aktivatör sistemi; serin proteaz ürokinaz plazminojen aktivatörü (uPA), iki endojen inhibitörü PAI-1 (plazminojen aktivatör inhibitör-1) ve PAI-2 ile uPA reseptöründen (uPAR veya CD87) oluşmaktadır. Bu çalışmada MM tanı, takip ve prognozunda akım sitometri metodunun ve CD87, CD45, CD56 ekspresyonunun önemini belirlemek amaçlanmıştır.

Yöntem ve Gereçler: Çalışmaya 29 MM hastası alındı. Akım sitometri için kemik iliği örneği kullanıldı. Hastalara akım sitometri yöntemi ile CD87, CD45, CD56, CD10, CD19, CD20, CD38, CD138'i içeren panel çalışıldı.
\end{abstract}


Bulgular: Çalışmamızda CD87; 8 (\% 27.5) olguda negatif, 9 (\% 31.1) olguda zayıf pozitif, 12 (\% 41.4) olguda ise kuvvetli pozitif bulundu. CD 45 (-) olgularda CD 87 ekspresyonu anlamlı olarak yüksek bulundu. Sonuç: Akım sitometri MM tanısı ve prognozu belirlemede önemli role sahiptir. MM'da CD87 ekspresyonunun prognostik rolünü belirlemek için çok sayıda hasta içeren daha fazla klinik çalışmaya ihtiyaç vardır. (Turk J Hematol 2010; 27: 182-9)

Anahtar kelimeler: Multipl miyelom, uPA, CD87 (uPAR), akım sitometri

\section{Introduction}

Multiple myeloma (MM) is a B-cell malignancy characterized by the proliferation of malignant plasma cells in the bone marrow. It accounts for $1 \%$ of all malignancies and 10\% of hematological malignancies [1]. The diagnosis of MM depends on the criteria of the 'International Myeloma Working Group' [2]. The International Staging System (ISS), which classifies patients into three prognostic groups according to their $\beta_{2}$-microglobulin $\left(\beta_{2}-\mathrm{M}\right)$ and albumin levels, is used for the staging of MM [3].

A number of prognostic factors have been defined for MM, including advanced age, low performance status, lactate dehydrogenase (LDH), albumin, C-reactive protein (CRP), $\beta_{2}$-M levels, plasma cell labeling index (PCLI), bone marrow microvessel density (MVD), myeloma subtype, disease stage, syndecan-1 (CD138) level, soluble interleukin-6 receptor (sIL-6R) levels, and cytogenetic abnormalities including hypodiploidy and chromosome 13 deletions [1].

Studies are still ongoing to determine the role of flow cytometry in the diagnosis and prognosis of MM. The report of the European Myeloma Network suggests that the primary flow cytometric gate should depend on CD38 vs CD138 expression and that the panel including CD19, CD45, CD56, CD20, CD117, CD28 and CD27 should be used for diagnoses, differential diagnoses and follow-up [4].

The urokinase plasminogen activator (UPA) system consists of serine protease uPA, two endogenous inhibitors of PAI-1 (plasminogen activator inhibitor-1) as well as PAI-2 and uPA receptors (uPAR or CD87). uPA is a serine protease transforming plasminogen into active plasmin [5,6]. CD87 has a number of regulatory effects on cell migration, leukocyte adhesion, chemotaxis, and signal transduction. Reports have suggested that malignant plasma cells expressed UPA and UPAR and that this active proteolytic system might have an effect on the bone marrow turnover in this disease. In addition, studies suggested that CD87 had a role in the pathogenesis of $\mathrm{MM}$ and was associated with the prognosis [7,8].

The studies have demonstrated that CD56 expression is determined at a rate of $72-78 \%$ in overall $\mathrm{MM}$ cases and is associated with poor prognosis [9-15]. CD45 is a tyrosine phosphatase expressed by hematopoietic cells. CD45 expression is demonstrated at a rate of $18 \%$ in $\mathrm{MM}$ cases and associated with a good prognosis [12,16-18]. Extramedullary disease is also observed in patients who are CD45-negative [10]. Therefore, CD87 expression was evaluated with CD56 and CD45 in our study.

In this study, we examined the frequency of CD87, CD45, and CD56 expressions and their association with other prognostic parameters such as age, $\beta_{2}-\mathrm{M}$ and albumin levels, genetic abnormalities, and disease stage and subtype. The main objective of the present study was to determine the significance of flow cytometry and CD87, CD45 and CD56 expressions in the diagnosis, follow-up and prognosis of MM.

\section{Material and Methods}

A total of 29 MM patients (23 newly diagnosed; 6 with relapse while under follow-up) were included in the study. The MM diagnosis was based on the medical history, clinical manifestations, immune fixation tests in urine and serum, immunoglobulin levels, and morphologic examination of the bone marrow. Age, hemoglobin ( $\mathrm{Hb})$ concentration, numbers of leukocytes and platelets, levels of plasma calcium $(\mathrm{Ca})$, creatinine $(\mathrm{Cr})$, albumin, $\mathrm{LDH}$, $\beta_{2}$-M and CRP, type of plasma M protein, type of free light chain in urine, the bone marrow biopsy, and the rate of plasma cells in the bone marrow of all the cases were registered. Using these parameters, the ISS stages were established [3]. The bone marrow samples of all cases were placed in $\mathrm{BD}$ Vacutainers containing standard (85 IU) amount of lithium heparin, for cytogenetic evaluation. Conventional cytogenetic evaluation of urine culture was conducted through 48 hours. 100 nuclei 
were assumed for each parameter and RB, IGH/ FGFR DC/DF and p53 probes were used for del 13q, $\mathrm{t}(4 ; 14)$ and del $17 \mathrm{p}$, respectively. Bone marrow samples were used for flow cytometry

\section{Material used in the study}

The acquisition and analyses of cells were carried out with the FACSCalibur device and Cell Quest program (BD Biosciences, Heidelberg, Germany) and monoclonal antibodies (BD Biosciences, Heidelberg, Germany). CD45 PER CP (peridininchlorophyll-protein), CD38 PE (phycoerythrin), CD138 FITC (fluorescein isothiocyanate), CD10 PE, CD19 PER CP, CD20 PER CP, CD56 PE, CD87 PE, cyt kappa FITC, cyt lambda PE, IgG1FITC, IgG1 Per CP, and IgG2a PE monoclonal antibodies were used.

\section{Procedure}

Bone marrow was directly examined by fluorescein stained (FITC, PE, PER CP) monoclonal antibodies. We used CD45/CD38/CD138/CD20, CD38/ CD138/CD19/CD87, CD45/CD38/CD19/CD56, CD38/ CD138/CD19/CD10, cytKappa/cyt Lambda/CD38/ CD19 combinations for multiparametric analysis. Following the reading of cells with the FACS CALIBUR device, they were analyzed with the CELL QUEST program. For the analysis, CD45 (-/dim+) and CD38 $(+)$ plasma cells at the CD45/CD38 dot blot were selected. Thereafter, CD38 (+) and CD138 (+) cells at the CD38/CD138 dot blot were selected. A gate for selected CD45 (-/dim+) CD38 (+) CD138 (+) plas- ma cells was drawn from the FSC-SSC dot blot and all analyses were carried out with the cells gated in this dot blot (Figure 1). The gating strategy was optimized to exclude contamination events, particularly apoptotic cells and cellular debris. Analysis of CD38 versus CD138 expression provides the best separation of plasma cells from other leukocytes, but is also subject to contamination, with cells binding antibodies nonspecifically. This can be detected on the CD38 versus CD45 plot to the right of the plasma cell population. Thus, an initial region (R1) is set around cells expressing high level of CD38 and CD138, and a second region (R2) is set on the light scatter of gated CD38+CD138+cells. A third region (R3) was set around the cells satisfying both R1 and R2 for CD38 and CD45 expression.

All samples were drawn after obtaining formal written consent from the patients, and the research was carried out in accordance with the Helsinki Declaration.

\section{Statistical Analysis}

Data were analyzed with the SPSS 11.5 package program. While descriptive statistics were expressed as mean \pm SD or median (min-max) for continuously measured variables, categorical variables were expressed as the number of observations and percentages. Mann-Whitney U test was used to compare two independent groups for characteristics such as age, immunoglobulin, ISS and CD87. When the number of independent groups was more than two, Kruskal-Wallis variance analysis was done for
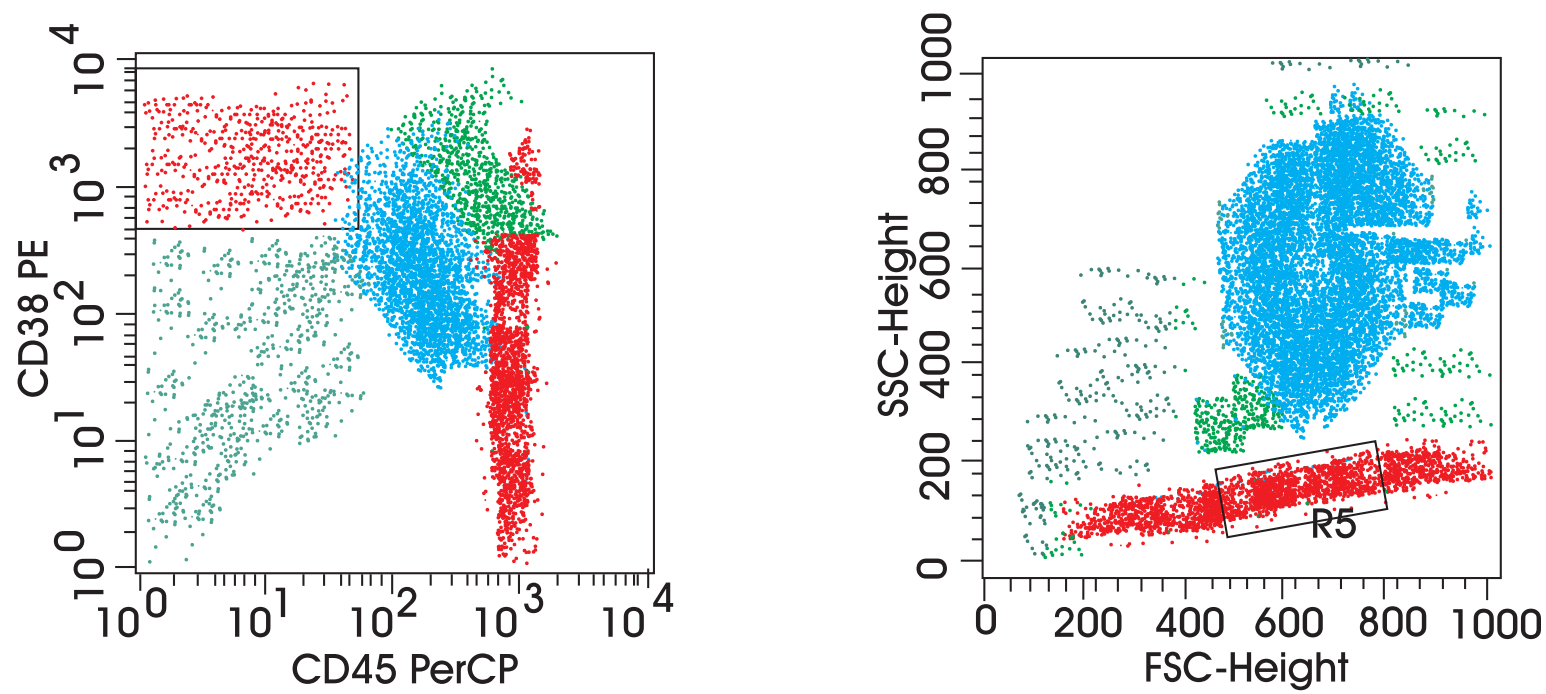

Figure 1. Selection of plasma cells by flow cytometry 
comparisons. Categorical comparisons were done using chi-square and Fisher's exact tests. A level of $\mathrm{p}<0.05$ was considered to be significant.

\section{Results}

A total of $29 \mathrm{MM}$ patients (20 males, 9 females) who were monitored in the Hematology Clinic were examined. While 23 patients (79\%) were newly diagnosed, $6(21 \%)$ had relapsed disease. Patients who were in the plateau phase or in remission were excluded. General characteristics of the patients are listed in Table 1.

A panel of CD87, CD45, CD56, CD10, CD19, CD20, CD38, and CD138 was tested by flow cytometry for each patient. Initially, samples were examined for CD38 and CD138 to support the MM diagnosis. All

Table 1. General characteristics of patients enrolled in the study $(n=29)$

\begin{tabular}{lc}
\hline Sex (female/male) & $9 / 20$ \\
Age ( $\leq 65 />65)$ & $15 / 14$ \\
Age (years, median/range) & $61.5(36-78)$ \\
Disease status (new diagnosis/relapse) & $23 / 6$ \\
Hb level (g/dL) ( $\leq 10 />10)$ & $13 / 16$ \\
Creatinine value (mg/dL) ( $\leq 1.3 />1.3)$ & $21 / 8$ \\
Lytic lesions (yes/no) & $20 / 9$ \\
IgG/IgA/light chain & $15 / 11 / 3$ \\
Free chain (kappa/lambda/none) & $13 / 15 / 1$ \\
ISS (stage I/stage II-III) & $12 / 17$ \\
Beta-2 microglobulin (mg/dL) ( $1.8 />1.8)$ & $13 / 16$ \\
CRP (mg/L) ( $\leq 5 />5)$ & $11 / 18$ \\
Sedimentation (mm/hr) (N/high) & $0 / 29$ \\
Extramedullary involvement (yes/no) & $6 / 23$ \\
Poor cytogenetic parameter & $15 / 14$ \\
[dell3q, 17p, $t(4 ; 14)]$ (yes/no) & \\
\hline
\end{tabular}

Hb: Hemoglobin; CRP: C-reactive protein; ISS: International Staging System

Table 2. Flow cytometric findings in patients

\begin{tabular}{lcc}
\hline & (n=29) & $\begin{array}{c}\text { \% (Mean) of } \\
\text { positive cases }\end{array}$ \\
\hline CD38 (-/+) & $0 / 29$ & $0 / 69.8$ \\
CD138 (-/+) & $0 / 29$ & $0 / 66.6$ \\
CD45 (-/+) & $19 / 10$ & $65.5 / 34.5$ \\
CD10 (-/+) & $29 / 0$ & $100 / 0$ \\
CD19 (-/+) & $28 / 1$ & $96.6 / 3.4$ \\
CD20 (-/+) & $24 / 5$ & $82.8 / 17.2$ \\
CD56 (-/+) & $8 / 21$ & $27.6 / 72.4$ \\
CD87 (negative-dim positive/bright positive) & $17 / 12$ & $58.6 / 41.4$
\end{tabular}

patients were CD38 and CD138 (+). CD138, CD87 and CD56 positivity by flow cytometry are shown in Figures 2, 3, and 4, respectively; Figure 5 shows concurrent positivity of CD38 and CD138. Flow cytometric findings are listed in Table 2.

Comparison of CD87 expression with other prognostic parameters is presented in Table 3. A significant correlation was present between CD87 and CD45 ( $\mathrm{p}=0.019)$. While CD87 expression was low (negative or dim) in cases who were CD45 (+), it was high (bright) in those who were CD45 (-). CD87 correlated significantly with extramedullary involvement $(\mathrm{p}=0.050)$. CD87 expression was bright $(+)$ in patients with extramedullary involvement (Table 3 ).

In CD45 (+) patients, low CD87 expression (negative or dim positive) was statistically significant $(p=0.019)$ (Table 3).

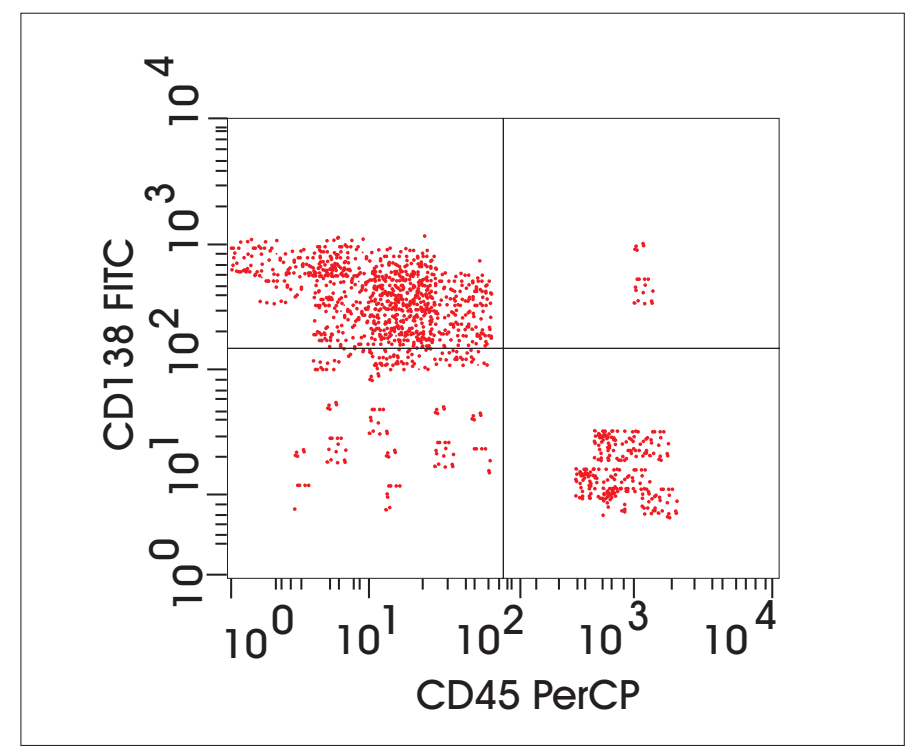

Figure 2. CD138 positivity in plasma cells

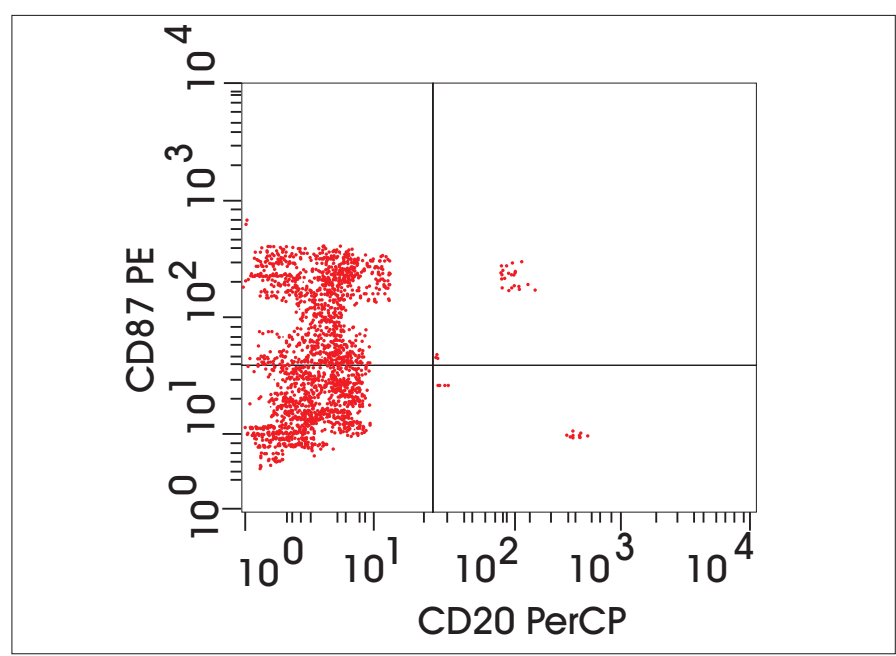

Figure 3. CD87 positivity in plasma cells 
There was no significant correlation between CD56 and CD87 ( $\mathrm{p}=1.000)$ (Table 3). Similarly, CD56 and CD45 did not correlate significantly $(p=0.201)$. CD56 positivity in plasma cells with flow cytometry is shown in Figure 4.

\section{Discussion}

The surface antigens detected by flow cytometric method have begun to be used in addition to the biochemical and genetic parameters in the diagnosis, follow-up and prognosis of MM [4]. Using flow cytometry, Rigolin et al. [19] determined neoplastic cells expressing CD87 in all of the 49 MM patients included in their study. The highest CD87 expres-

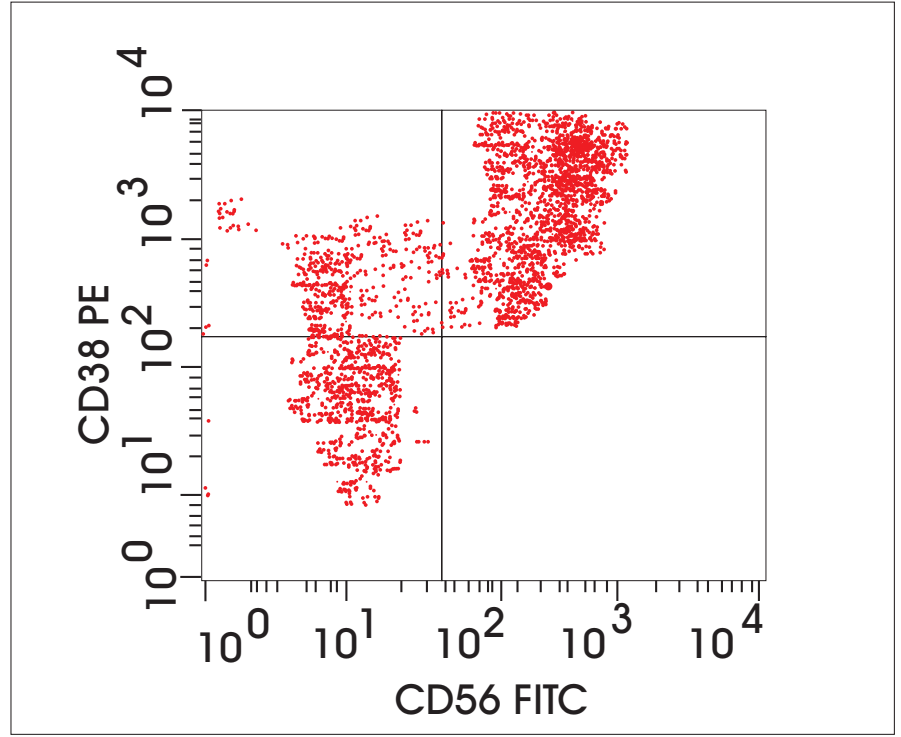

Figure 4. CD56 positivity in plasma cells

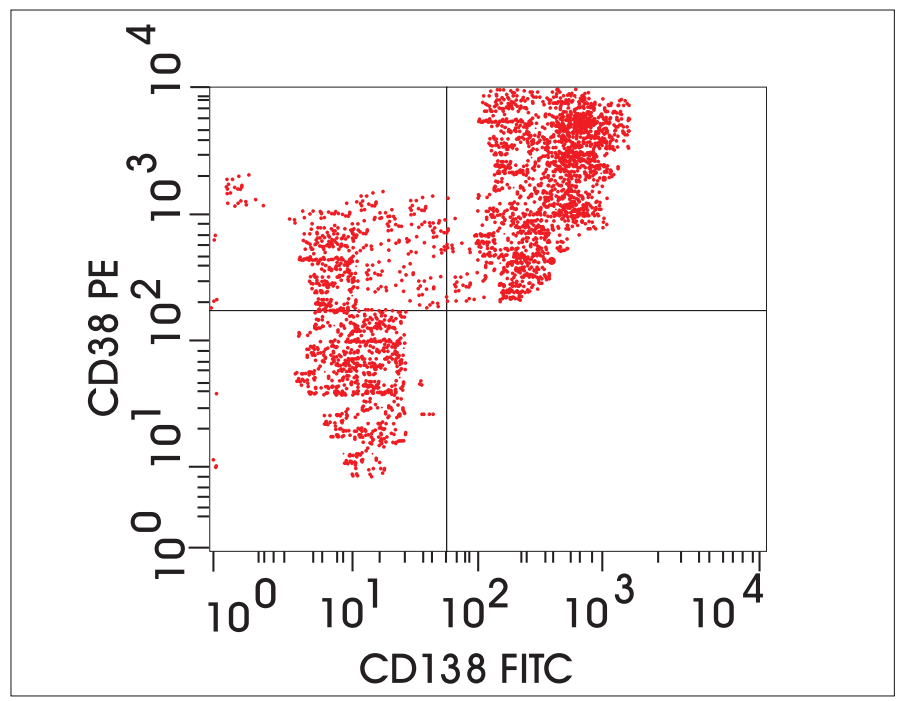

Figure 5. Concurrent positivity of CD38 and CD138 in plasma cells sion was by CD45 (+) immature plasma cells; in addition, these cells displayed strong reactivity against CD138 and CD56, which are two important molecules for the cell adhesion process. In MM patients, CD87 expression seems to be inversely related to the maturation of malignant plasma cells. This suggests that CD87, like CD56, may be involved in the regulation of plasma cell organization and consequently in the disease pathogenesis [7,9].

We used CD38 and CD138 to diagnose MM and to differentiate malignant plasma cells. CD38 and CD138 were positive in all cases (Table 2). This finding was in accordance with the data in the literature. In a study by Plesner et al. [20] including 31 patients, the percentage of $\mathrm{CD} 38(++)$ cells was

Table 3. Comparison of CD87 expression with prognostic parameters

\begin{tabular}{|c|c|c|c|c|}
\hline & & $\begin{array}{l}\text { D87 negative } \\
\text { dim positive } \\
(n=17)\end{array}$ & $\begin{array}{c}\text { CD87 bright } \\
\text { positive } \\
(\mathrm{n}=12)\end{array}$ & $\begin{array}{c}\mathrm{p} \\
\text { value }\end{array}$ \\
\hline \multicolumn{2}{|l|}{ CD45 (-) } & 8 & 11 & 0.019 \\
\hline \multicolumn{2}{|l|}{ CD45 (+) } & 9 & 1 & \\
\hline \multicolumn{2}{|l|}{ CD56 (-) } & 5 & 3 & 1.000 \\
\hline \multicolumn{2}{|l|}{ CD6 $(+)$} & 12 & 9 & \\
\hline \multirow[t]{2}{*}{ EM involvement } & Yes & 1 & 5 & 0.050 \\
\hline & No & 16 & 7 & \\
\hline \multicolumn{2}{|l|}{ CD20 (-) } & 13 & 11 & 0.370 \\
\hline \multicolumn{2}{|l|}{ CD20 (+) } & 4 & 1 & \\
\hline \multicolumn{2}{|l|}{ Age } & 17 & 12 & 0.412 \\
\hline \multirow[t]{4}{*}{ Sex } & Male & 10 & 10 & 0.234 \\
\hline & Female & 7 & 2 & \\
\hline & $\mathrm{Hb} \leq 10$ & 9 & 4 & 0.296 \\
\hline & $>10$ & 8 & 8 & \\
\hline \multirow{2}{*}{$\begin{array}{l}\text { Creatinine value } \\
(\mathrm{mg} / \mathrm{dL})\end{array}$} & $\leq 1.3$ & 11 & 10 & 0.408 \\
\hline & $>1.3$ & 6 & 2 & \\
\hline \multirow[t]{2}{*}{ Lytic lesions } & Yes & 6 & 3 & 0.694 \\
\hline & No & 11 & 9 & \\
\hline \multirow[t]{2}{*}{ ISS } & Stage I & 7 & 5 & 1.000 \\
\hline & Stage II and III & III 10 & 7 & \\
\hline \multirow[t]{2}{*}{$\beta 2-\mathrm{M}(\mathrm{mg} / \mathrm{dL})$} & $\leq 1.8$ & 7 & 6 & 0.638 \\
\hline & $>1.8$ & 10 & 6 & \\
\hline \multirow{2}{*}{$\begin{array}{l}\mathrm{CRP}(\mathrm{mg} / \mathrm{L}) \\
\text { between }\end{array}$} & $0-5$ & 5 & 6 & 0.438 \\
\hline & $>5$ & 12 & 6 & \\
\hline \multirow[t]{2}{*}{ 13q14 del. } & Yes & 7 & 7 & 0.462 \\
\hline & No & 10 & 5 & \\
\hline
\end{tabular}

EM: Extramedullary involvement; Hb: Hemoglobin; CRP: C-reactive protein; ISS: International Staging System; $\beta 2-\mathrm{M}$ : Beta-2 microglobulin 
considered as the percentage of myeloma cells. Lin et al. [12] suggested that CD138 was the most specific marker for plasma cells, and that staining was 70-100\%, but reported that for the initial differentiation of plasma cells, the CD38, CD138 and CD45 combination was more effective. Aberrant CD56 expression was detected in $71.7 \%$ of MM cases [12]. CD56 differentiates malignant and benign plasma cells [11]. Aggressive disease and extramedullary involvement are common in myeloma cases without CD56 expression [13].

A study by Mathew et al. [13] including 68 cases demonstrated that survival was shorter in CD56 (-) myeloma cases compared to those who were CD56 (+). In another study, 8 among 12 CD56 (-) myeloma cases were either refractory or progressive [21]. Sahara et al. [15] also examined 70 patients and found that 15 cases were CD56 (-) and 55 were CD56 (+). In this study, high $\beta 2$-M level, extramedullary disease, thrombocytopenia, and renal involvement were significantly more common in patients who were CD56 (-) compared to CD56 (+) cases. Survival was significantly lower in CD56 (-) cases (22 months) than in CD 56 (+) patients (63 months) [15]. In the present study, 21 among 29 patients (72\%) were CD56 (+), in accordance with the previous data. However, we could not find any correlation between CD56 and other prognostic factors.

CD45 expression is variable in myeloma cells. While immature plasma cells stain CD45 bright $(+)$, mature plasma cells stain either CD45 (-) or CD45 $\operatorname{dim}(+)$ [22]. Asosingh et al. [23] suggested that CD45 (+) myeloma patients had a longer survival. Moreau et al. [24] reported that while CD45 (-) myeloma patients had a poor prognosis, the prognosis of CD45 $(+)$ cases was good.

In compliance with the above-mentioned data, CD87 expression was significantly higher in CD45 (-) patients in our study. Lin et al. [12] reported that 54 among 306 cases (17.6\%) expressed CD45. In our study, in 10 among 29 patients (34.5\%), CD45 expression was positive; CD45 expression did not correlate significantly with other prognostic parameters.

In a study by Hjertner et al. [8] including 7 cases, UPA and UPAR were expressed by myeloma cells and all patients had CD87 expression. Similarly, Rigolin et al. [19] reported CD87 expression in all of their patients $(n=49)$. On the other hand, Plesner et al. [20] could not detect uPAR in any of their patients in a series including 10 cases. Although the reason for this difference is unclear, variations in myeloma cell isolation were suggested to account for the difference in UPAR expression [20]. CD87 expression was bright $(+)$ in 12 patients among 29 (41.5\%) and -/dim positive in 17 (58.5\%).

While immature plasma cells stain CD45 bright $(+)$, mature plasma cells stain either (-) or dim (+) $[22,25,26]$. The expression of CD87 by CD45 (+) immature plasma cells is 5-17 times higher than by CD45 -/dim + mature plasma cells. The study by Hjertner et al. [8] showed that uPAR expression depended on myeloma cell maturation and that immature myeloma cells had high expression levels. Rigolin et al. [19] classified 49 patients into two groups according to CD87 expression. Patients with high CD87 expression also had high CD56, CD38, CD138 and high CD45 positivity.

The studies have demonstrated that prognosis was poor in CD45 (-) myeloma patients and good in CD45 $(+)$ cases $(23,24)$. In our study, CD87 expression was significantly higher in CD45 (-) cases, and the rate of extramedullary involvement, which is associated with poor prognosis, was also significantly higher in this group.

However, uPAR expressions are highly variable in myeloma patients. This was suggested to be associated with the translocation of uPAR stored in the cytoplasmic compartment on the cell surface after being activated, and following uPA/PAI-1 internalization and degradation in lysosomes, its return to the cell surface $[8,20]$.

Lanza et al. [27] reported a significant correlation between high CD87 expression in acute leukemias and extramedullary involvement. This suggests an association of uPAR expression with clinical features predicting a more aggressive disease course [27]. We found a significant correlation between CD87 expression and extramedullary involvement. Patients with extramedullary involvement had higher CD87 expression. However, there was no correlation between CD87 and other prognostic parameters (Table 3 ).

Rigolin et al. [19] determined an association between high CD87 expression and lytic bone lesions. However, we could not demonstrate such a correlation in our study. On the other hand, while Rigolin et al. could not find a correlation between circulatory soluble uPAR and UPAR (CD87), suPAR seemed to correlate with an aggressive disease course. High suPAR levels were associated with advanced disease, high Cr levels, high CD138 and high $\beta_{2}$-M levels. However, this study was not able to demonstrate a 
significant correlation between suPAR level and CRP and $13 q 14$ deletion [19]. No other studies detected a significant relation between CD87 expression and 13q14 deletion in myeloma patients [7]. Similarly, in our study, CD87 expression and the 13q14 deletion did not correlate significantly.

CD87 (UPAR) is expressed by myeloma cells and is likely to have a pivotal role in the biology of the disease. Moreover, serum uPAR is an independent parameter that predicts extramedullary involvement and poor prognosis in myeloma [19].

In conclusion, immunophenotyping by flow cytometry is a sensitive method that is used for the diagnosis and clinical monitoring of the disease. Flow cytometry in MM is beneficial in detecting malignant plasma cells and prognostic markers and monitoring the development and differentiation of myeloma cells. CD87, CD45 and CD56 should be tested for the prediction of prognosis in MM. However, further clinical studies including large numbers of patients are needed to determine the prognostic role of CD87.

\section{Acknowledegement}

Ethical committee approval was obtained in this study.

\section{Conflict of Interest}

No author of this paper has a conflict of interest, including specific financial interests, relationships, and/or affiliations relevant to the subject matter or materials included in this manuscript.

\section{References}

1 Tricot G. Multiple myeloma and other plasma cell disorders. In: Hoffman R, Benz EJ, Shattil SJ, Furie B, Cohen HJ, Silberstein LE, McGlave P, editors. Hematology Basic Principles and Practice. 4th ed. Philadelphia: Elsevier Science, 2005:1501-21.

2 International Myeloma Working Group. Criteria for the classification of monoclonal gammopathies, multiple myeloma and related disorders: a report of the International Myeloma Working Group. Br J Haematol 2003;121:749-57.

3 Greipp PR, San Miguel J, Durie BG, Crowley JJ, Barlogie B, Bladé J, Boccadoro M, Child JA, Avet-Loiseau H, Kyle RA, Lahuerta JJ, Ludwig H, Morgan G, Powles R, Shimizu K, Shustik C, Sonneveld P, Tosi P, Turesson I, Westin J. International staging system for multiple myeloma. J Clin Oncol 2005;23:3412-20.

4. Rawstron AC, Orfao A, Beksac M, Bezdickova L, Brooimans RA, Bumbea H, Dalva K, Fuhler G, Gratama
J, Hose D, Kovarova L, Lioznov M, Mateo G, Morilla R, Mylin AK, Omedé P, Pellat-Deceunynck C, Perez Andres M, Petrucci M, Ruggeri M, Rymkiewicz G, Schmitz A, Schreder M, Seynaeve C, Spacek M, de Tute RM, Van Valckenborgh E, Weston-Bell N, Owen RG, San Miguel JF, Sonneveld P, Johnsen HE; European Myeloma Network. Report of the European Myeloma Network on multiparametric flow cytometry in multiple myeloma and related disorders. Haematologica 2008;93:4318. Epub 2008 Feb 11.

5. Duffy MJ. The urokinase plasminogen activator system: role in malignancy. Curr Pharm Des 2004;10:39-49.

6. Bu G, Warshawsky I, Schwartz AL. Cellular receptors for the plasminogen activators. Blood 1994;83:3427-36.

7. Béné MC, Castoldi G, Knapp W, Rigolin GM, Escribano L, Lemez P, Ludwig WD, Matutes E, Orfao A, Lanza F, van't Veer M; EGIL, European Group on Immunological Classification of Leukemias. CD 87 (Urokinase-type plasminogen activator receptor), function and pathology in hematological disorders: a review. Leukemia 2004;18:394-400.

8. Hjertner O, Qvigstad G, Hjorth-Hansen H, Seidel C, Woodliff J, Epstein J, Waage A, Sundan A, Börset M. Expression of urokinase plasminogen activator and the urokinase plasminogen activator receptor in myeloma cells. Br J Haematol 2000;109:815-22.

9. Pellat-Deceunynck C, Bataille R, Robillard N, Harousseau JL, Rapp MJ, Juge-Morineau N, Wijdenes J, Amiot M. Expression of CD 28 and CD 40 in human myeloma cells: a comparative study with normal plasma cells. Blood 1994;84:2597-603.

10. Pellat-Deceunynck C, Barille S, Puthier D, Rapp MJ, Harousseau JL, Bataille R, Amiot M. Adhesion molecules on human myeloma cells: significant changes in expression related to malignancy, tumor spreading, and immortalization. Cancer Res 1995;55:3647-53.

11. Pellat-Deceunynck C, Barille S, Jego G, Puthier D, Robillard N, Pineau D, Rapp MJ, Harousseau JL, Amiot M, Bataille R. The absence of CD 56 (NCAM) on malignant plasma cells is a hallmark of plasma cell leukemia and of a special subset of multiple myeloma. Leukemia 1998;12:1977-82.

12. Lin P, Owens R, Tricot G, Wilson CS. Flow cytometric immunophenotypic analysis of 306 cases of multiple myeloma. Am J Clin Pathol 2004;121:482-8.

13. Dahl IM, Rasmussen T, Kauric G, Husebekk A. Differential expression of CD 56 and CD 44 in the evolution of extramedullary myeloma. $\mathrm{Br} \mathrm{J}$ Haematol 2002;116:273-7.

14. Mathew P, Ahmann GJ, Witzig TE, Roche PC, Kyle RA, Greipp PR. Clinicopathological correlates of CD 56 expression in multiple myeloma: a unique entity? Br J Haematol 1995;90:459-61.

15. Sahara N, Takeshita A, Shigeno K, Fujisawa S, Takeshita K, Naito K, Ihara M, Ono T, Tamashima S, Nara K, Ohnishi K, Ohno R. Clinicopathological and prognostic characteristics of CD 56 negative multiple myeloma. $\mathrm{Br}$ J Haematol 2002;117:882-5. 
16. Moreau P, Robillard N, Jego G, Pellat C, Le Gouill S, Thoumi S, Avet-Loiseau H, Harousseau JL, Bataille R. Lack of CD 27 in myeloma delineates different presentation and outcome. Br J Haematol 2006;132:168-70.

17. Moreau P, Robillard N, Avet-Loiseau H, Pineau D, Morineau N, Milpied N, Harousseau JL, Bataille R. Patients with CD45 negative multiple myeloma receiving high-dose therapy have a shorter survival than those with CD45 positive multiple myeloma. Haematologica 2004;89:547-51.

18. Kawano MM, Ishikawa H, Tsuyama N, Abroun S, Liu S, Li FJ, Otsuyama K, Zheng X. Growth mechanism of human myeloma cells by interleukin-6. Int J Hematol 2002;76(Suppl 1):329-33.

19. Rigolin GM, Tieghi A, Ciccone M, Bragotti LZ, Cavazzini F, Della Porta M, Castagnari B, Carroccia R, Guerra G, Cuneo A, Castoldi G. Soluble urokinase-type plasminogen activator receptor (suPAR) as an independent factor predicting worse prognosis and extra-bone marrow involvement in multiple myeloma patients. $\mathrm{Br} \mathrm{J}$ Haematol 2003;120:953-9.

20. Plesner T, Behrendt N, Ploug M. Structure, function and expression on blood and bone marrow cells of the urokinase-type plasminogen activator receptor, uPAR. Stem Cells 1997;15:398-408.

21. Van Camp B, Durie BG, Spier C, De Waele M, Van Riet I, Vela E, Frutiger Y, Richter L, Grogan TM. Plasma cells in multiple myeloma express a natural killer cell-associated antigen: CD 56 (NKH-1:leu-19). Blood 1990;76:377-82.
22. Schneider U, Van Lessen A, Huhn D, Serke S. Two subsets of peripheral blood plasma cells defined by differential expression of CD45 antigen. Br J Haematol 1997;97:56-64.

23. Asosingh K, Willems A, Van Riet I, Van Camp B, Vanderkerken K. Delayed in vivo disease progression is associated with high proportions of CD $45+$ myeloma cells in the 5T2 MM murine model. Cancer Res 2003;63:3019-20.

24. Moreau P, Robillard N, Avet-Loiseau H, Pineau D, Morineau N, Milpied N, Harousseau JL, Bataille R. Patients with CD45 negative multiple myeloma receiving high-dose therapy have a shorter survival than those with CD45 positive multiple myeloma. Haematologica 2004;89:547-51.

25. Hata H, Xiao H, Petrucci MT, Woodliff J, Chang R, Epstein J. Interleukin-6 gene expression in multiple myeloma: a characteristic of immature tumor cells. Blood 1993;81:3357-64.

26. Joshua D, Petersen A, Brown R, Pope B, Snowdon L, Gibson J. The labelling index of primitive plasma cells determines the clinical behaviour of patients with myelomatosis. Br J Haematol 1996;94:76-81.

27. Lanza F, Castoldi GL, Castagnari B, Todd RF 3rd, Moretti S, Spisani S, Latorraca A, Focarile E, Roberti MG, Traniello $\mathrm{S}$. Expression and functional role of urokinase-type plasminogen activator receptor in normal and acute leukaemic cells. Br J Haematol 1998;103:110-23. 